\title{
PERAN PPNS DAERAH DALAM UPAYA PENEGAKAN PERATURAN DAERAH
}

\author{
Heriyanto', Mustofa ${ }^{2}$ \\ 1,2Prodi Hukum Ekonomi Syariah, Fakultas Syariah \\ Universitas Ibrahimy, Situbondo Jawa Timur
}

Email: ${ }^{1}$ heriyanto.muhammad@gmail.com, ${ }^{2}$ mustofalutfi6@gmail.com

\begin{abstract}
Abstraks
Dalam menjalankan urusan pemerintahan yang efektif dan berwibawa diperlukan sebuah instrumen hukum bagi PPNS Daerah dalam menjalankan peran dan fungsinya. Berdasarkan latar belakang tersebut maka dapat dirumuskan, bagaimana instrumen hukum yang menjadi landasan yuridis bagi Penyidik Pegawai Negeri Sipil Daerah dalam melakukan penegakan Peraturan Daerah? Penelitian ini menggunakan metode yang berbasiskan metode penelitian hukum Yuridis Normatif. Guna menghindari upaya/ perilaku "main hakim" ditengahtengah masyarakat, sebagai peran Pemerintah adalah menjaga ketertiban dalam masyarakat melalui Peraturan Daerah juga berkewajiban menegakkan peraturan daerah yang telah dibuat dan diberlakukan, berdasarkan peraturan perundangundangan yang berlaku. Sistem hukum yang ada dan berlaku didaerah harus berjalan beriringan, khususnya agenda penegakan hukum atas peraturan daerah. Penting untuk dipahami bersama bahwa, wibawa pemerintah daerah ditentukan oleh sistem penegakan hukum yang berlaku.
\end{abstract}

Kata Kunci : Pemerintah Daerah, PPNS, Daerah.

\begin{abstract}
In carrying out effective and authoritative government affairs, a legal instrument is needed for Regional PPNS in carrying out their roles and functions. Based on this background, it can be formulated, how is the legal instrument that becomes the juridical basis for Regional Civil Servant Investigators in enforcing Regional Regulations? This study uses a method based on normative juridical research methods. In order to avoid the effort / behavior of "playing the judge" in the midst of society, as the role of the Government is to maintain order in society through Regional Regulations it is also obliged to enforce regional regulations that have been made and enforced, based on applicable laws and regulations. The existing and applicable legal system in the region must go hand in hand, especially the law enforcement agenda for regional regulations. It is important to understand that the local government's authority is determined by the applicable law enforcement system.
\end{abstract}

Keywords : Local Government, PPNS, Region. 


\section{PENDAHULUAN}

\section{A. Latar Belakang}

Negara Indonesia, dalam UUD pasal 1 ayat (1) menyatakan secara tegas sebagai Negara Kesatuan yang berbentuk Republik. Apabila dilihat dari konsepsi dasar, Negara Kesatuan terdapat asas bahwa segenap urusan-urusan negara tidak dibagi antara Pemerintah Pusat (central government) dengan Pemerintah Daerah (local government), karena semua urusan pemerintahan dalam Negara Kesatuan tetap merupakan suatu kebulatan (eenheid), sehingga pemegang kekuasaan tertinggi negara adalah Pemerintah Pusat. ${ }^{1}$ Akan tetapi dalam UUD mengatur sistem Pemerintahan yang menganut asas Negara Kesatuan berdasarkan prinsip desentralisasi, berdasarkan hal tesebut maka menjadi suatu keharusan untuk membuat berbagai peraturan (rules) sebagai dasar hukum dalam menjalankan urusan daerah, sehingga konsep desentralisasi berjalan sesuai amanah konstitusi.

Dalam UUD pasca amandemen, konstitusi memberikan porsi yang cukup besar kepada daerah otonom 2 terkait dengan urusan pemerintahan seperti yang termaktub dalam UUD 1945 Pasal 18 Ayat(2)bahwa :

"Pemerintahan Daerah provinsi, daerah kabupaten, dan kota mengatur dan mengurus sendiri urusan pemerintahan menurut asas otonomi dan tugas pembantuan. Serta ayat (6): Pemerintahan Daerah berhak menetapkan peraturan daerah dan peraturan-peraturan lain untuk melaksanakan otonomi dan tugas pembantuan "

Setiap Daerah sesuai karakter Daerahnya akan mempunyai prioritas yang berbeda antara satu Daerah dengan Daerah lainnya. Ini merupakan pendekatan yang bersifat asimetris artinya walaupun Daerah sama-sama diberikan otonomi yang seluas-luasnya, namun prioritas Urusan Pemerintahan yang dikerjakan akan berbeda satu Daerah dengan Daerah lainnya. Konsekuensi logis dari pendekatan asimetris tersebut maka Daerah akan mempunyai prioritas Urusan Pemerintahan dan kelembagaan yang berbeda satu dengan lainnya sesuai dengan karakter Daerah dan kebutuhan masyarakatnya.

\footnotetext{
${ }^{1}$ Ni`matul Huda, Hukum Pemerintahan Daerah, ctk. pertama, (Bandung: Nusa Media 2009), hal. 43.

2 Daerah otonom atau daerah, adalah kesatuan masyarakat hukum yang mempunyai batas-batas wilayah yang berwenang mengatur dan mengurus urusan pemerintahan dan kepentingan masyarakat setempat menurut prakarsa sendiri berdasarkan aspirasi masyarakat dalam sistem Negara Kesatuan Republik Indonesia. Pasal 1 ayat (12) UU Nomor 23 Tahun 2014
} 
Sebuah kewajiban bagi pemerintah daerah untuk mewujudkan kesejahteraan dan keadilan masyarakat, terlebih disaat pemerintah daerah dituntut untuk menyiapkan diri guna menghadapi arus globalisasi serta menjawab tantangan modernisasi tanpa harus merubah atau bahkan kehilangan jati diri sebagai kota santri, karena semakin modern sebuah daerah semakin besar atau semakin beragam bentuk perilaku pelanggaran terhadap ketentuan-ketentuan yang berlaku didaerah. Oleh sebab itu, sebuah keharusan bagi pemerintah daerah untuk melakukan berbagai inovasi guna kepentingan masyarakat yang tentu harus didukung oleh regulasi (Perda / Perkada) yang baik.

Dalam menjalankan urusan pemerintahan yang efektif dan berwibawa diperlukan sebuah Peraturan Daerah (Perda) selain memuat ketentuan- ketentuan yang berlaku pada umumnya juga memuat ketentuan mengenai sanksi. Selain hal tersebut, merupakan sebuah kewajiban hukum bagi pemerintah untuk melakukan penegakan atas Perda yang berlaku. Khusus mengenai hal penegakan peraturan daerah tentu membutuhkan perangkat daerah / pejabat daerah yang mempunyai dan menuntut tingkat profesionalisme tinggi.

Guna kepentingan penegakan Perda dan Perkada, berdasarkan Pasal 255 ayat (2) Undang-undang Nomor 23 Tahun 2014 jo. Undang-undang Nomor 9 Tahun 2015 tentang pemerintahan Daerah, Satuan polisi pamong prajadibentuk khusus untuk menegakkan Perda dan Perkada, menyelenggarakan ketertiban umum dan ketenteraman, serta menyelenggarakan pelindungan masyarakat, bahwa :

Satuan polisi pamong praja mempunyai kewenangan:

a. melakukan tindakan penertiban non-yustisial terhadap warga masyarakat, aparatur, atau badan hukum yang melakukan pelanggaran atas Perda dan/atau Perkada;

b. menindak ${ }^{3}$ warga masyarakat, aparatur, atau badan hukum yang mengganggu ketertiban umum dan ketenteraman masyarakat;

c. melakukan tindakan penyelidikan terhadap warga masyarakat, aparatur, atau badan hukum yang diduga melakukan pelanggaran atas Perda dan/atau Perkada;

d. melakukan tindakan administratif terhadap warga masyarakat, aparatur, atau badan hukum yang melakukan pelanggaran atas Perda dan/atau Perkada.

${ }^{3}$ Yang dimaksud dengan "menindak" adalah melakukan tindakan hukum terhadap pelanggaran Perda untuk diproses melalui peradilan sesuai dengan ketentuan peraturan perundang-undangan. Peraturan pemerintah Nomor 6 Tahun 2010 Tentang Satuan Polisi Pamong Praja 
Penegakan Perda secara umum menjadi tanggungjawab Satuan Polisi Pamong Praja daerah, tetapi lain halnya dengan tindakan penyidikan atas pelanggaran Perda sebagai bagian dari proses penegakan hukum atas pelanggaran Perda. Maka berdasarkan Pasal 1 ayat (1) Keputusan Menteri Dalam Negeri Nomor 7 tahun 2003 tentang Pedoman Operasional Penyidik Pegawai negeri sipil daerah (PPNSD) dalam penegakan peraturan daerah, bahwa :

PPNS Daerah, adalah Pejabat Pegawai Negeri Sipil tertentu di Lingkungan Pemerintah Daerah yang diberi wewenang khusus oleh Undang-undang untuk melakukan penyidikan terhadap pelanggaran Peraturan Daerah. Adapun tugas dari PPNSD adalah melakukan penyidikan4 terhadap orang, aparatur dan/atau badan hukum yang diduga melakukan pelanggaran Perda, dalam hal Pelaksanaan Operasi penegakan Peraturan Daerah dapat dilakukan dalam bentuk operasi non- yustisi5 dan atau yustisi6 dengan mekanisme sidang ditempat.

Dalam sistem peradilan pidana, keberadaan Penyidik Pegawai Negeri Sipil (PPNS) secara umum dapat dilihat dari ketentuan Pasal 1 ayat (1) KUHAP, yang menyatakan bahwa penyidik adalah pejabat polisi negara Republik Indonesia atau pejabat pegawai negeri sipil tertentu yang diberi wewenang khusus oleh undangundang untuk melakukan penyidikan. Selain itu terdapat dalam ketentuan Pasal 1 angka 11 UU No.2 Tahun 2002 tentang kepolisian merupakan pejabat pegawai negeri sipil tertentu yang berdasarkan peraturan perundang-undangan ditunjuk selaku penyidik dan mempunyai wewenang untuk melakukan penyidikan tindak pidana dalam lingkup undang-undang yang menjadi dasar hukumnya masing-masing.

\footnotetext{
${ }^{4}$ Penyidikan adalah serangkaian tindakan penyidik dalam hal dan menurut cara tertentu untuk mencari serta mengumpulkan bukti yang dengan bukti itu, membuat terang tentang tidak pidana yang terjadi dan guna menemukan tersangka, dalam Pasal 1 ayat (3) KEPMENDAGRI No. 7 Tahun 2003 tentang Keputusan Menteri Dalam Negeri Tentang Pedoman Operasional Penyidik Pegawai Negeri Sipil Daerah Dalam Penegakan Peraturan Daerah

5 Tindakan penertiban nonyustisial adalah tindakan yang dilakukan oleh Polisi Pamong Praja dalam rangka menjaga dan/atau memulihkan ketertiban umum dan ketenteraman masyarakat terhadap pelanggaran Perda dan/atau peraturan kepala daerah dengan cara yang sesuai dengan ketentuan peraturan perundangundangan

Dan tidak sampai proses peradilan. Pasal 6 huruf (a) Peraturan pemerintah Nomor 6 Tahun 2010 Tentang Satuan Polisi Pamong Praja

${ }^{6}$ Operasi Yustisi adalah operasi penegakan Peraturan Daerah dan Peraturan Perundangan-undangan yang dilakukan oleh PPNS secara terpadu dengan sistim peradilan ditempat. Pasal 1 Ayat (8) KEPMENDAGRI No. 7 Tahun 2003 tentang Keputusan Menteri Dalam Negeri Tentang Pedoman Operasional Penyidik Pegawai Negeri Sipil Daerah Dalam Penegakan Peraturan Daerah
} 
Kemudian lebih lanjut dalam pelaksanaan tugas sebagai penyidik, PPNS diatur dalam Pasal 6 ayat (1) huruf b KUHAP, yaitu pegawai negeri sipil yang mempunyai fungsi dan wewenang sebagai penyidik. Pada dasarnya, wewenang yang dimiliki bersumber pada undang-undang tertentu, yang telah menetapkan sendiri pemberian wewenang penyidikan pada salah satu pasal. Adapun wewenang penyidikan yang dimiliki oleh pejabat pegawai negeri sipil hanya terbatas sepanjang yang menyangkut dengan tindak pidana yang diatur dalam undang-undang pidana khusus itu. Hal ini sesuai dengan pembatasan wewenang yang disebutkan dalam Pasal 7 ayat (2) KUHAP yang berbunyi:

"Penyidik pegawai negeri sipil sebagaimana dimaksud Pasal 6 ayat (1) huruf b mempunyai wewenang sesuai dengan undang-undang yang menjadi landasan hukumnya masing-masing dan dalam pelaksanaan tugasnya berada dibawah koordinasi dan pengawasan penyidik Polri"

Berdasarkan ketentuan tentang PPNS sebagaimana dalam KUHAP (lex generalis) tersebut, maka Penyidik Pejabat Negeri Sipil (PPNS) pada umumnya dan khususnya PPNS7 ialah bagian dari Aparatur Sipil Negara yang diberi wewenang khusus berdasarkan UU No.23 Tahun 2014 tentang Pemerintahan Daerah untuk melakukan penyidikan dan penyelidikan terhadap orang dan/atau badan hukum yang diduga melakukan pelanggaran Perda dan Perkada (lex specialis).

Sebagai salah satu dari fungsi pemerintah daerah adalah sebagai regulator dalam hierarki perundang-undangan, maka Peraturan Daerah tentang Penyidik Pegawai Negeri Sipil Daerah dapat dundangkan sebagai dasar kebutuhan dan mengisi kekosongan hukum dalam sistem hukum penegakan Perda. Dengan mempertimbangkan berbagai aspek tersebut perlu diterbitkan Peraturan Daerah tentang Penyidik Pegawai Negeri Sipil secara spesifik berdasarkan ketentuan Perundang- Undangan yang berlaku.

\footnotetext{
${ }^{7}$ Dalam peraturan perundang-undangan istilah PPNSD ditemukan dalam PP No.58 Tahun 2010 tentang pelaksanaan KUHAp dan KEPMENDAGRI No. 7 Tahun 2003 tentang Keputusan Menteri Dalam Negeri Tentang Pedoman Operasional Penyidik Pegawai Negeri Sipil Daerah Dalam Penegakan Peraturan Daerah
} 


\section{B. Rumusan Masalah}

Berdasarkan uraian pada Latar Belakang maka dapat dirumuskan, bagaimana instrumen hukum yang menjadi landasan yuridis bagi Penyidik Pegawai Negeri Sipil Daerah dalam melakukan penegakan Peraturan Daerah?

\section{Motode Penelitian}

Penelitian ini menggunakan metode yang berbasiskan metode penelitian hukum Yuridis Normatif. Adapun metode sebagai berikut: menggunakan pendekatan Peraturan Perundang-undangan adalah pendekatan dengan menggunakan legeslasi dan regulasi. Pendekatan Peraturan Perundang-undangan dilakukan dengan menelaah semua peraturan perundang-undangan yang berkaitan dengan Penyidik Pegawai Negeri Sipil Daerah.

Jenis data yang digunakandalampenyusunan naskah akademik iniberasaldari data primer dan data sekunder, sebagaiberikut: Data primer, ialah data yang diperoleh secara langsung dari Peraturan Perundang-Undangan yang berkaitan dengan Penyidik Pegawai Negeri Sipil Daerah. Data sekunder, ialah data pendukung yang diperoleh dari studi kepustakaan, misalnya dari buku-buku, media cetak maupun media elektronik yang berkaitan dengan Penyidik Pegawai Negeri Sipil Daerah.

TeknikPengumpulan Data, memperhatikan jenis data yang ada, maka teknik pengumpulan data yang digunakan adalah Studi Dokumen yaitu pengumpulan data dengan menggunakan dokumen-dokumen seperti media cetakdan internet yang memuat berita tentang Penyidik Pegawai Negeri Sipil Daerah yang diteliti diluar data pustaka guna melengkapi data-data yang diperlukan. Analisis Data menggunakan metode Preskriptif yaitu suatuan analisa dengan menggunakan cara mengumpulkan data yang diperoleh dan menjelaskan secara terang dan jelas, kemudian menganalisa dan memberikan solusi atas permasalahan yang diangkat, sehingga nantinya akan dapat ditarik suatu kesimpulan dari permasalahan yang ada.

\section{PEMBAHASAN}

Kata kunci dari otonomi daerah adalah "kewenangan". Seberapa besarkah "kewenangan" yang dimiliki oleh daerah didalam menginisiatifkan kebijaksanaan, implementasikannya, dan memobilisasi dukungan sumber daya untuk kepentingan implementasi. Dengan kewenangan maka Daerah akan menjadi kreatif untuk 206 HUKMY | Jurnal Hukum 
menciptakan kelebihan dan insentif kegiatan ekonomi dan pembangunan daerah. Dengan kewenangan dan kreatifitas maka akan dapat meningkatkan pendapatan keuangan daerah. ${ }^{8}$ Konsekuensi dari otonomi ini adalah, memungkinkan daerah bebas untuk berimprovisasi, mengekspresikan dan mengapresiasikan kemampuan dan potensi yang dimiliki, mempunyai kebebasan berpikir dan bertindak, sehingga bisa berkarya sesuai dengan kebebasan daerah masing-masing. ${ }^{9}$ Menurut S.H. Sarundajang, hakikat otonomi daerah ini adalah: ${ }^{10}$ Otonomi adalah hak mengurus rumah tangga sendiri bagi suatu daerah otonom; Otonomi merupakan suatu kebebasan menjalankan hak mengurus dan mengatur rumah tangga sendiri, akan tetapi daerah tidak dapat menjalankan hak dan wewenang otonominya itu diluar batas wilayah daerahnya; Otonomi tidak boleh mencampuri hak mengatur dan mengurus rumah tangga daerah lain sesuai dengan wewenang pangkal dan urusan yang diserahkan kepadanya. dan, Otonomi tidak membawahi otonomi lain, hak mengatur dan mengurus rumah tangga sendiri tidak merupakan subordinasi hak mengatur dan mengurus rumah tangga daerah lain.

Menurut Rasyid dalam tataran konsep, pengertian desentralisasi dan otonomi daerah mempunyai tempatnya masing-masing. Istilah otonomi daerah lebih cenderung pada political aspect (aspek politik-kekuasaan negara), sedangkan desentralisasi lebih cenderung pada administrative aspect (aspek administrasi negara). Namun dilihat dari konteks sharing of power (berbagi kekuasaan), dalam prakteknya, kedua istilah tersebut mempunyai keterkaitan yang erat, dan tidak dapat dipisahkan. Artinya jika berbicara mengenai otonomi daerah, tentu akan menyangkut pertanyaan seberapa besar untuk menyelenggarakan urusan pemerintahan yang telah diberikan sebagai wewenang rumah tangga daerah. ${ }^{11}$

\footnotetext{
${ }^{8}$ Ibad, S. Kewenangan Badan Perencanaan Pembangunan Kota (Bappeko) Malang Dalam Perencanaan, Kordinasi, Dan Pengendalian Tata Ruang Kota. DIALEKTIKA : Jurnal Ekonomi Dan Ilmu Sosial, 1(2), 23-48 2018. https://doi.org/10.36636/dialektika.v1i2.68

${ }^{9}$ Heriyanto, otonomi daerah bidang Pertanahan. Karya tulis ilmiah. (Yogyakarta FH UII. 2010), hal. 23

10 S.H. Sarundajang, Arus Balik Kekuasaan Pusat ke Daerah, (Jakarta, Pustaka Sinar Harapan, 2000), hal. 34.

11 Ryaas Rasyid, Makna Pemerintahan : tinjauan dari segi etika dan kepemimpinan, (Jakarta, Yarsif Watampone, 2000), hal. 78.
} 
Secara implisit hal ini juga mengindikasikan bahwa tujuan utama yang hendak dicapai dalam desentralisasi meliputi, terwujudnya demokratisasi tingkat lokal, terciptanya efisiensi dan efektifitas penyelenggaraan pemerintahan daerah dan peningkatan kesejahteraan di daerah. Keberadaan Penyidik Pegawai Negeri Sipil (PPNS) melekat pada suatu institusi di pusat dan daerah yang berkoordinasi langsung dibawah pengawasan Kepolisian Republik Indonesia, PPNS adalah pegawai negeri sipil tertentu sebagaimana dimaksud dalam KUHAP, baik yang berada di pusat maupun daerah yang diberi wewenang khusus oleh undang undang, ${ }^{12}$ selanjutnya pada Pasal 2, Pejabat Penyidik Pegawai Negeri Sipil dijelaskan bahwa yang dimaksud dengan Penyidik adalah: pertama penyidik adalah Pejabat Kepolisian Negara Republik Indonesia; dan kedua penyidik adalah Pejabat Pegawai Negeri Sipil.

Selanjutnya juga di jelaskan dalam Peraturan Menteri Dalam Negeri Nomor 11 Tahun 2009 yaitu Penyidik Pegawai Negeri Sipil Daerah yang selanjutnya disebut PPNS Daerah, adalah Pegawai Negeri pejabat Pegawai Negeri Sipil tertentu di lingkungan Pemerintah Daerah yang diberi wewenang khusus oleh Undang-Undang untuk melakukan penyidikan terhadap pelanggaran Peraturan Daerah, ${ }^{13}$ tentunya sebagai PenyidikPegawai Negeri Sipil Daerah (PPNSD) dalam melaksanakan tugas dan tanggungjawabnya mengacu pada pedoman PPNSD,14 untuk itulah lahir Peraturan Meneteri Dalam Negeri Nomor 11 Tahun 2009 Tentang Kode Etik Penyidik Pegawai Negeri Sipil Daerah dengan memiliki karakteristik pada Kode Etik Profesi Penyidik Pegawai Negeri Sipil Daerah yaitu norma yang digunakan sebagai pedoman yang harus ditaati oleh PPNSD dalam melaksanakan tugas, sesuai dengan prosedur penyidikan, ketentuan peraturan perundang-undangan, dan Perda PPNS Daerah yang berlaku dengan menjunjung tinggi Hak Asasi Manusia serta prinsip-prinsip yangmendasarinya yaitu: Integritas, yaitu memiliki kepribadian yang dilandasi oleh unsur jujur, berani, bijaksana dan bertanggungjawab, Kompetensi, yaitu memiliki pengetahuan, keahlian, pengalaman, dan keterampilan yang diperlukan dalam melaksanakan tugasnya, Obyektifitas yaitu menjunjung tinggi ketidakperpihakan dalam melaksanakan

\footnotetext{
12Peraturan Pemerintah Republik Indonesia Nomor 58 Tahun 2010 Tentang Perubahan Atas Peraturan Pemerintah Nomor 27 Tahun 1983 Tentang Pelaksanaan Kitab Undang-Undang Hukum Acara Pidana

13Peraturan Menteri Dalam Negeri Nomor 11 Tahun 2009 Tentang Kode Etik Penyidik Pegawai Negeri Sipil Daerah

${ }^{14}$ Keputusan Menteri dalam Negeri no. 7 tahun 2003 Tentang Pedoman Operasi PPNSD
} 
tugasnya, dan Independensi, yaitu tidak terpengaruh adanya tekanan atau kepentingan pihak manapun. ${ }^{15}$

Penyidik Pegawai Negeri Sipil bertugasmelakukan Penyidikan dan Penyelidikan kejahatan dan pelanggaran atas Peraturan Daerah dan Perkada yang melibatkan aparatur atau masyarakat atau badan hukum. PPNS mempunyai peranan penting dan merupakan ujung tombak dalam proses penegakan hukum pidana dalam konteks pelanggaran Perda/perkada. Kinerja penyidik berpengaruh besar dalam proses penanganan perkara pidana, selanjutnya fungsi PPNS antara lain menerima laporan atau pengaduan dari seseorang mengenai adanya kejahatan dan pelanggaran atas Peraturan Daerah, melakukan peningkatan kualitas PPNS, membuat Berita Acara Pemeriksanaan (BAP) setiap tindakan pelangaran. ${ }^{16}$

Kemudian peran dan tugas pokok PPNS Satpol PP merupakan tugas tindak lanjutan yang diserahkan oleh Satpol PP dalam melaksanakan penertiban umum, ketenteraman masyarakat dan melindungi masyarakat yang menimbulkan perkara hukum, sebagaimana telah dipertegas pada Peraturan Pemerintah Nomor 6 Tahun 2010 Tentang Kesatuan Polisi Pamong Praja pada pasal 8 ayat e, dalam setiap menjalankan dan melaksanakan peran dan tugasnya, Polisi Pamong Praja wajib, menjunjung tinggi norma hukum, norma agama, hak asasi manusia, dan norma sosial lainnya yang hidup dan berkembang di masyarakat, menaati disiplin pegawai negeri sipil dan kode etik Polisi Pamong Praja, membantu menyelesaikan perselisihan warga masyarakat yang dapat mengganggu ketertiban umum dan ketenteraman masyarakat, melaporkan kepada Kepolisian Negara Republik Indonesia atas ditemukannya atau patut diduga adanya tindak pidana, menyerahkan kepada Penyidik PegawaiNegeri Sipil daerah atas ditemukannya atau patut diduga adanya pelanggaran terhadap Perda dan/atau peraturan kepala daerah. ${ }^{17}$

Sistem peradilan pidana adalah suatu proses penegakan hukum dengan pendekatan sistem yang di dalamnya terdapat subsistem/ komponen yang terdiri dari kepolisian, kejaksaan, pengadilan dan lembaga pemasyarakatan Dalam

\footnotetext{
15Jurnal Bina Praja. Volume 5 Nomor 4 Edisi Desember 2013, hal. 221 - 232

16Ibid

17 Pasal 8 Peraturan Pemerintah Nomo 6 Tahun 2010 Tentang Kesatuan Polisi Pamong Praja
} 
perkembangannya, komponen atau subsistem tersebut berkembang dengan dimasukannya komponen Advokat dalam subsistem peradilan pidana sebagaimana dijelaskan dalam UU No. 18 Tahun 2003 tentang Advokat.18

Sehingga jika dilihat lebih lanjut dari segi kelembagaan, PPNS bukan merupakan subordinasi dari lembaga kepolisian yang merupakan bagian dari Sistem Peradilan Pidana (Criminal Justice System). Sebagaimana diketahui bahwa sistem peradilan pidana di Indonesia mengenal 5 (lima) institusi sub sistem peradilan pidana sebagai Panca Wangsa penegak hukum, yaitu Lembaga Kepolisian (UU No. 2 Tahun 2002), Kejaksaan (UU No. 16 Tahun 2004), Peradilan (UU No. 49 Tahun 2009 tentang Perubahan Kedua atas UU No. 2 Tahun 1986), Lembaga Pemasyarakatan (UU No. 12 Tahun 1995) dan Advokat (UU No. 18 Tahun 2003).19

Sehingga dapat dikatakan bahwa PPNS merupakan penyidik, disamping penyidik POLRI yang memiliki kedudukan serta berperan penting dalam melakukan penyidikan, dalam kaitannya menegakkan hukum pidana. Adapun PPNS mendapatkan kewenangan untuk menyidik berdasarkan Undang-Undang yang menjadi dasar hukumnya dalam melaksanakan fungsi kepenyidikannya tetap berada dibawah koordinasi dan pengawasan Penyidik Polri berdasarkan peraturan yang berlaku, sehingga penyidikan yang dilaksanakan oleh PPNS terbatas dan menyangkut pelanggaran/tindak pidana yang diatur dalam undang-undang tersebut.

Berdasarkan Pasal 15 Ayat (2) Undang-undang Nomo 23 Tahun 2014 tentang Pemerintahan daerah, bahwa Perda dapat memuat Ketentuan pidana berupa ancaman pidana kurungan paling lama 6 (enam) bulan atau pidana denda paling banyak Rp. 50.000.000,00 (lima puluh juta rupiah). Maka berdasarkan ketentuan tersebut, sebagai konsekwensi dalam penegakan hukum dalam hal dilakukan melalui penindakan secara yustisi, maka yang harus menjadi perhatian adalah hukum acara yang hendak digunakan sebagai alternatif dalam model penindakan atas pelanggaran Perda.

${ }^{18}$ Pasal 5 ayat (1) dan Pasal 9 (2) Undang Undang Nomor 18 Tahun 2003 tentang Advokat

${ }^{19}$ Lilik Mulyadi, Bunga Rampai Hukum Pidana: Perspektif, Teoretis dan Praktik, (Bandung Alumni,2008), Hal.7 
Berdasarkan Hukum Acara pidana, pemeriksaan perkara dipersidangan dapat dilakukan dengan Acara Pemeriksaan Biasa, ${ }^{20}$ Singkat, ${ }^{21}$ dan Cepat. ${ }^{22}$ Sehingga Penting untuk dipahami bagi PPNS dalam melakukan Penyidikan atas pelanggaran Perda, guna menentukan jenis penindakan yang berimplikasi pada acara pemeriksaan.

Berdasarkan Peraturan Menteri Dalam Negeri Nomor 54 Tahun 2011 tentang SOP Sat.Pol.PP ;

1. Penindakan preventif non yustisial; Tindakan yang dilakukan oleh Satuan Polisi Pamong Praja:

a Penindakan terhadap para pelanggar Peraturan daerah, terlebih dahulu menanda tangani surat pernyataaan bersedia dan sanggup mentaati dan mematuhi serta melaksanakan ketentuan dalam waktu 15 hari terhitung sejak penandatanganan surat pernyataan.

b Apabila tidak melaksanakan dan atau mengingkari syaratpernyataannya, maka akan diberikan: 1). Surat teguran pertama, dengan tegang waktu 7(tujuh) hari; 2). Surat teguran kedua dengan tegang waktu 3 (tiga) hari; 3). Surat teguran ketiga, dengan tegang waktu 3 (tiga) hari

c Apabila tidak melaksanakan dan atau mengingkari surat teguran tersebut, akan dilaporkan kepada Penyidik Pegawai Negeri Sipil (PPNS) untuk dilakukan proses sesuai peraturan perundang undangan yang berlaku.

2. Penindakan yustisi; PPNS dalam rangka penyelidikan pelanggaran Peraturan daerah (Trantibum) dapat menggunakan kewenangan pengawasan dan ataupengamatan untuk menemukan pelanggaran pidana dalam lingkupundangundang yang menjadi dasar hukumnya (peraturan daerah).

\footnotetext{
${ }^{20}$ Yang diperiksa menurut Acara Biasa merupakan pemeriksaan yang dilakukan berdasarkan Pasal 152202 KUHAP, yaitu tindak pidana yang pembuktiannya mudah, serta penerapan hukumnya tidak mudah serta sifat melawan hukumnya tidak sederhana.

21 Yang diperiksa menurut acara pemeriksaan singkat ialah perkara kejahatan atau pelanggaran yang tidak termasuk ketentuan Pasal 205 dan yang menurut penuntut umum pembuktian serta penerapan hukumnya mudah dan sifatnya sederhana. Pasal 203 KUHAP

22 Yang diperiksa menurut Acara Cepat ialah perkara yang diancam dengan pidana penjara atau kurungan paling lama 3 (tiga) bulan dan atau denda sebanyak-banyaknya tujuh ribu lima ratus rupiah dan penghinaan ringan. Pasal 205 KUHAP
} 
Berikut yang menjadi landasan Yuridis PPNS Daerah, diantaranya ialah :

1. Undang-undang Dasar Negara Republik 1945 (Konstitusi RI)

BAB VI tentang Pemerintahan Daerah, bahwa dalam Pasal 18 secara keseluruhan sebagai dasar hukum tentang pemerintahan daerah berikut juga dengan pelaksanaan prinsip-prinsip otonomi daerah, dekonsentrasi dan desentralisasi. Dalam pasal ini juga sebagai dasar hukum atas kewenangan Pemerintah daerah membuat produk hukum daerah (PERDA). UUD 1945 sebagai puncak teratas hierarkhi pembentukan perundangundangan RI.

2. Undang undang Nomor 8 TAHUN 1981 tentangHukum Acara Pidana (KUHAP)

Disebutkan dalam Pasal 1 angka (1), bahwa Sebagai dasar pembentukan dan diakuinya Pejabat / Pegawai Negeri Sipil sebagai bagian dari penyidik pada penegakan hukum pidana (lex generalis). Kemudian pasal 6 ayat (1), bahwaKeberadaan Penyidik Pegawai Negeri Sipil untuk melaksanakan tugas penyidikan yang diberi wewenang khusus berdasarkan undang-undang tertentu (lex specialis). Selanjutnya dalam Pasal 7, bahwaPPNS dalam menjalankan fungsi dan tugasnya berada dibawah koordinasi Kepolisian.

3. PP No. 58 Tahun 2010 Perubahan PP No. 27 Tahun 1983 Tentang Pelaksanaan Kitab Undangundang Hukum Acara Pidana

Dalam Pasal 1 ayat (6), memberikan definisi yang jelas, bahwa PPNS adalah pegawai negeri sipil tertentu sebagaimana dimaksud dalam KUHAP, baik yang berada di pusat maupun daerah yang diberi wewenang khusus oleh undang-undang. Kemudian dalam Pasal 3A, ketentuan tentang syarat-syarat untuk dapat diangkat sebagai PPNS. Untuk dapat diangkat sebagai pejabat PPNS, calon harus memenuhi persyaratan sebagai berikut: a). masa kerja sebagai pegawai negeri sipil paling singkat 2 (dua) tahun; b). berpangkat paling rendah Penata Muda/golongan III/a; c). berpendidikan paling rendah sarjana hukum atau sarjana lain yang setara; d). bertugas di bidang teknis operasional penegakan hukum; e). sehat jasmani dan rohani yang dibuktikan dengan surat keterangan dokter pada rumah sakit pemerintah.

4. Undang undang Nomor 2 Tahun 2002 tentang Kepolisian Negara

Ditentukan dalam Pasal 3, bahwa Keberadaan PPNS ialah untuk membantu Kepolisian dalam mengemban fungsi penyidikan sesuai dengan peraturan perundang undangan yang menjadi dasar hukum masing-masing PPNS. Kemudian dalam 
pelaksanaannya. Disebutkan dalam Pasal 14 bahwa Polri melaksanakan fungsi koordinasi, pengawasan, dan pembinaan teknis PPNS. Selain itu dalam Pasal 16, bahwa Polri memberi bantuan dan petunjuk penyidikan terhadap PPNS, serta menerima hasil penyidikan untuk kemudian diserahkan pada penuntut Umum.

5. Undang-Undang Nomor 9 Tahun 2015 tentang Perubahan Atas Undang-Undang Nomor 23 Tahun 2014 tentang Pemerintahan Daerah

Sebagai dasar Pembentukan perda disebutkan dalam Pasal 235, bahwa Pemerintah Daerah Kabupaten / Kota diberi wewenang untuk melakasanakan dan mengurus urusan pemerintah daerah (desentralisasi) sebagai daerah otonom. Kemudian Pemerintah daerah melalui PPNS memiliki kewenangan menegakkan Perda, sebagimana Pasal 257, bahwa Penyidik terhadap pelanggaran Perda dilakukan oleh PPNS. Hal ini Sebagai dasar bagi pemerintah daerah untuk memiliki PPNS dalam melakukan penyidikan terhadap pelanggar peraturan daerah yang berlaku pada masing-masing daerah otonom.

6. Peraturan Pemerintah Republik Indonesia Nomor 58 Tahun 2005 tentang pengelolaan keuangan daerah

Bahwa untuk kepentingan menjalankan fungsi dan segala kewenangan PPNS di kabupaten Situbondo, maka dibutuhkan sebuah paket anggaran dalam menjalankan tugas penyidikan dalam menegakkan perda, kewenangan untuk mengelola anggaran sebagaimanadisebutkan dalam Pasal 5, kepala daerah memegang kekuasaan pengelolaan keuangan daerah.

7. Undang undang Nomor 12 Tahun 2011 Tentang Pembentukan Peraturan Perundang-Undangan

Ditentukan dalam Pasal 5, tentang asas asas pembentukan Peraturan perundang-undangan. Bahwa dalam setiap penyusunan produk hukum harus berdasarkan / taat terhadap asas yang dimaksud dalam undang-undang ini. Kemudian dalam Pasal 7, mengatur tentang hierarkii peraturan perundang undangan. Kemudian Pasal 63, tentang tatacara / mekanisme perumusan Perda kabupaten/kota.

8. Undang-Undang Republik Indonesia Nomor 5 Tahun 2014 Tentang Aparatur Sipil Negara (ASN) 
Bahwa sebagai syarat untuk diangkat sebagai PPNS harus berstatus sebagai Pegawai Negeri Sipil, maka dalam PPNS secara personal terikat dan melekat dengan segala peraturan tentang kepegawaian sebagaimana dimaksud dalam undang-undang ini. Disebutkan dalam Pasal 21, mengatur tentang hak Aparatur Sipil Negera. Kemudian Pasal 23, mengatur tentang kewajiban Aparatur Sipil Negara.

9. Peraturan Pemerintah Republik Indonesia Nomor 79 Tahun 2005 tentang Pedoman Pembinaan, Pengawasan Penyelenggaraan pemerintahan Daerah

Bahwa untuk kepentingan menjalankan fungsi dan segala kewenangan pemerintahan di kabupaten Situbondo. Disebutkan dalam Pasal 20 ayat (4) inspektorat kabupaten/kota melakukan pengawasan terhadap pelaksanaan urusan pemerintahan di daerahkabupaten/kota;

10. Peraturan Pemerintah Nomor 41 Tahun 2007 tentang Organisasi Perangkat Daerah

Pasal 2 menyebutkan, bahwa Pembentukan Organisasi Perangkat Daerah ditetapkan dengan peraturan daerah mengatur mengenai susunan, kedudukan, tugas pokok organisasi perangkat daerah.

11. Peraturan Pemerintah Nomor 43 TAHUN 2012 Tentang Tata Cara Pelaksanaan Koordinasi, Pengawasan, Dan Pembinaan Teknis Terhadap Kepolisian Khusus, Penyidik Pegawai Negeri Sipil, Dan Bentuk-Bentuk Pengamanan Swakarsa

Dalam peraturan ini disebutkan bahwa segala aktifitas penyidikan harus berada dibawah pengawasan dan koordinasi penyidik Polri, sebagaimana dalam Pasal 2, Polri melakukan koordinasi, Pengawasan, dan pembinaan PPNS, dalam bidang operasional pengamanan, pencegahan dan penangkalan, serta penindakan non-yustisiil.

12. Peraturan Pemerintah Nomor 6 Tahun 2010 tentang Satuan Polisi Pamong Praja

Polisi Pamong Praja sebagai perangkat daerah yang diberi wewenang khusus dalam menegakkan perda, disebutkan dalam Pasal 3, Pol PP adalah bagian dari perangkat daerah dalam penegakan perda dan penyelenggaraan ketertiban umum. Kemudian dalam Pasal 6, Pol PP berwenang melakukan penyelidikan terhadap warga, aparatur, dan badan hukum yang melanggar perda. Selanjutnya Pasal 9, Pol PP yang memenuhi syarat sebagai PPNS dapat langsung mengadakan penyidikan pelanggaran perda.

13. Peraturan Menteri Dalam Negeri Republik Indonesia Nomor 80 Tahun 2015 TentangPembentukan Produk Hukum Daerah 
Pembentukan produk hukum daerah diperlukan pedoman berdasarkan cara dan metode yang pasti, baku dan standar sehingga tidak bertentangan dengan peraturan perundang-undangan yang lebih tinggi, kepentingan umum dan/atau kesusilaan. Pasal 4 ayat (2), Perda memuat materi muatan: a). penyelenggaraan otonomi daerah dan tugas pembantuan; dan b). penjabaran lebih lanjut ketentuan peraturan perundangundangan yang lebih tinggi.

14. Peraturan Menteri Dalam Negeri Nomor 54 Tahun 2011 tentang Standar Operasional Prosedur Satuan Polisi Pamong Praja

Sebagai perangkat daerah yang secara khusus melaksanakan penegakan perda, dan PPNS menjadi salah satu organ satu-satunya yang memiliki tugas penyidikan, maka guna menghindari tumpang tindih tugas maka dibuat SOP khusus Pol.PP sebagaimana dalam Pasal 3, SOP Sat Pol PP bertujuan untuk keseragaman pelaksanaan tugas Pol PP dalam penegakan perda.

15. Keputusan Menteri Dalam Negeri No. 7 Tahun 2003 tentang Pedoman Operasional Penyidik Pegawai Negeri Sipil Daerah Dalam Penegakan Peraturan Daerah

Bahwa dalam rangka meningkatkan penegakan atas pelanggaran Peraturan Daerah secara optimal, maka pelaksanaan operasional Penyidik Pegawai Negeri Sipil Daerah perlu dilakukan secara terkoordinasi, terarah, terpadu dan berkesinambungan.Disebutkan dalam Pasal 2, Ruang lingkup oprasional PPNS daerah terdiri:a). Rencana dan Kegiatan penyidikan; b). administrasi penyidikan; c). pembinaan dan pengawasan dan pengendalian.

16. Peraturan Menteri Dalam Negeri Nomor 31 Tahun 2009 tentang Pedoman Penyelenggaraan Pendidikan dan Pelatihan Penyidik Pegawai Negeri Sipil Daerah;

Bahwa dalam rangka meningkatkan profesionalisme Penyidik Pegawai Negeri Sipil Daerah dalam melakukan penyidikan atas pelanggaran Peraturan Daerah dan peraturan perundang-undangan lainnya, perlu diselenggarakan pendidikan dan pelatihan Penyidik Pegawai Negeri Sipil Daerah secara terarah, terpadu, terkoordinasi, dan berkesinambungan. Disebutkan dalam Pasal 2, Pendidikan dan Pelatihan Penyidik Pegawai Negeri Sipil Daerah guna meningkatkan profesionalisme PPNS Daerah dalam melaksanakan penyidikan atas pelanggaran Peraturan Daerah dan peraturan perundang-undangan lainnya. 
17. Peraturan Menteri Dalam Negeri Nomor 11 Tahun 2009 tentang Kode Etik Penyidik Pegawai Negeri Sipil Daerah

Disebutkan dalam Pasal 2, PPNS dalam menjalankan tugas dan fungsinya berdasarkan prinsip: 1. Integritas; 2. Kompetensi; 3. Obyektifitas; 4. Indepedensi. Kemudian dalam Pasal 3, mengatur tentang kode etik PPNS. dalam rangka pelaksanaan tugas dan fungsi Penyidik Pegawai Negeri Sipil Daerah secara profesional dan akuntabel diperlukan tenaga Penyidik Pegawai Negeri Sipil Daerah yang memiliki integritas, kompetensi, obyektifitas, dan independensi dalam menjalankan tugasnya;

18. Peraturan menteri Hukum dan HAM Nomor M.HH.01.AH.09.01 Tahun 2011 Tentang Tata Cara Pengangkatan, Pemberhentian, Mutasi, Dan Pengambilan Sumpah Atau Janji Pejabat Penyidik Pegawai Negeri Sipil,

Bahwa Menteri Hukum dan Ham adalah lembaga yang memiliki kewenangan untuk mengangkat dan melantik PPNS, sebagaimana disebutkan dalam Pasal 2, PPNS diangkat dan disumpah oleh KEMENKUMHAM, berdasarkan syarat-syarat yang ditentukan KEMENKUMHAM. Namun khusus PPNS berdasarkan Pasal 7, bahwa PPNS Daerah dilantik dan disumpah oleh Kanwil KEMENKUMHAM.

19. Peraturan Kepala Kepolisian Negara Republik Indonesia Nomor 6 Tahun 2010 Tentang Manajemen Penyidikan Oleh Penyidik Pegawai Negeri Sipil Penyidik Pegawai Negeri Sipil

Penyidik Pegawai Negeri Sipil menurut Peraturan Kepala Kepolisian Negara Republik Indonesia Nomor 6 Tahun 2010 Tentang Manajemen Penyidikan Oleh Penyidik Pegawai Negeri Sipil Penyidik Pegawai Negeri Sipilyang selanjutnya disingkat PPNS adalah Pejabat Pegawai Negeri Sipil tertentu yang diberi wewenang khusus oleh undang-undang untuk melakukan penyidikan tindak pidana sesuai undang-undang yang menjadi dasar hukumnya masing-masing dan dalam pelaksanaan tugasnya berada di bawah koordinasi dan pengawasan Penyidik Polri dengan demikian jelas bahwa PPNS dibawah koordinasi dan pengawasan Kepolisian Republik Indonesia.

Demi terwujudnya ketertiban dan ketentraman masyarakat merupakan suatu hal yang absolut bagi pemerintah daerah dalam menegakkan hukum dalam bentuk mekanisme penindakan yang berkeadilan guna terciptanya kesejahteraan masyarakat yang merupakan esensi dari otonomi daerah. Dalam hal penindakan atau penerapan 
sanksi atas pelanggaran hukum terdapat dua fungsi dari asas pemidanaan, yakni fungsi fundamental dan fungsi teori. ${ }^{23}$

Pertama, fungsi fundamental yaitu sebagai landasan dan asas normatif atau kaidah yang memberikan pedoman, kriteria atau paradigma terhadap masalah pidana dan pemidanaan. Fungsi ini secara formal dan intrinsik bersifat primer dan terkandung di dalam setiap ajaran sistem filsafat. Maksudnya, setiap asas yang ditetapkan sebagai prinsip maupun kaidah itulah yang diakui sebagai kebenaran atau norma yang wajib ditegakkan, dikembangkan dan diaplikasikan. ${ }^{24} \mathrm{Kedua}$, fungsi teori dalam hal ini sebagai meta teori. Maksudnya, filsafat pemidanaan berfungsi sebagai teori yang mendasari dan melatar belakangi setiap pemidanaan. Bedasarkan kedua fungsi di atas dalam proses implementasinya, penetapan sanksi pidana dan tindakan merupakan aktivitas program legislasi dan/atau yudikasi untuk menormatifkan jenis dan bentuk sanksi (pemidanaan) sebagai landasan keabsahan penegakan hukum melalui penerapan sanksi. ${ }^{25}$

Dalam penegakan hukum, model keadilan didasarkan pada tujuan pencegahan dan retribusi, bahwa pencegahan bertujuan mencegah pengulangan pelanggaran dikemudian hari. Sedangkan retribusi memusatkan pada kerugian yang ditimbulkan oleh perbuatan pelanggar dan dimaksudkan untuk memastikan untuk membayar sanksi yang dilakukannya. Ganjaran yang setimpal menjelaskan konsepsi retribusi yang mendasari bukan balas dendam, lebih tepatnya adalah beratnya sanski seharusnya didasarkan atas beratnya perbuatan. ${ }^{26}$ Dalam setiap agenda penegakan hukum (pidana) yang berkeadilan, proses Penyidikan merupakan tahap awal mekanisme Sistem Peradilan Pidana (SPP). Penyidikan mempunyai kedudukan dan peranan yang sangat penting dan strategis untuk menentukan berhasil tidaknya proses penegakan hukum pidana selanjutnya. Pelaksanaan penyidikan yang baik dan menentukan keberasilan Jaksa penuntut umum dalam melakukan penuntutan dan selanjutnya memberikan

\footnotetext{
${ }^{23}$ Teguh Prasetyo, Kriminalisasi Dalam Hukum Pidana, (Bandung: Nusa Media, 2010) hal. 109

${ }^{24}$ Ibid

${ }^{25}$ Ibid

${ }^{26}$ Ibid, hal. 105-106
} 
kemudahanbagi hakim untuk menggali/menemukan kebenaran materiil dalam memeriksa dan mengadili di persidangan. ${ }^{27}$

Guna menghindari upaya / perilaku "main hakim" ditengah-tengah masyarakat, sebagai peran Pemerintah adalah menjaga ketertiban dalam masyarakat melalui Peraturan Daerah juga berkewajiban menegakkan peraturan daerah yang telah dibuat dan diberlakukan, berdasarkan peraturan perundang-undangan yang berlaku. Sistem hukum yang ada dan berlaku didaerah harus berjalan beriringan, khususnya agenda penegakan hukum atas peraturan daerah. Penting untuk dipahami bersama bahwa, wibawa pemerintah daerah ditentukan oleh sistem penegakan hukum yang berlaku.

\section{KESIMPULAN}

Bahwa berdasarkan konstitusi, Pemerintah daerah mempunyai kewenangan menjalankan prinsip otonomi daerah sebagaimana amanah dari undang-undang tentang pemerinthan daerah. Selain dari pada itu pemerintah daerah juga mempunyai kewenangan dalam membuat produk hukum daerah serta melaksnakan penegakan atas pelanggaran Perda.

Bahwa kemudian berlakunya Perda tentang Penyidik Pegawai Negeri Sipil Daerah, adalah merupakan sebuah jawaban dari segala kebuntuan yang selama ini dihadapi oleh pemerintah kabupaten situbondo dalam melakukan penegakan hukum atas pelanggaran Perda. Maraknya pelanggar Perda dengan berbagai jenis pelanggaran perda menjadikan sebuah tuntutan bagi pemerintah daerah ntuk melakukan penegakan hukum secara profesional dengan menerbitkan Peraturan Daerah tentang PPNS Daerah, sebagai legitimasi bagi PPNS kabupaten dalam melaksanakan kewenangan penyidikan sebagai bagian dari mekanisme penindakan bagi para pelanggar Perda. Bahwa dengan adanya Peraturan Daerah yang mengatur khusus tentang PPNS dapat memberikan kerangka penegakan Peraturan daerah dan mempersiapkan PPNS yang profesional sebagai upaya pemerintah daerah dalam menekan angka pelanggaran perda dan terciptanya kondisi masyarakat yang tentram dan tertib, sehingga terwujudnya kesejahteraan masyarakat.

27Zulkarenaen Koto, Terobosan Hukum Dalam Penyederhanaan Proses Peradilan Pidana, (Jakarta : Jurnal Studi Kepolisian, STIKI, 2011) hal.150 


\section{DAFTAR PUSTAKA}

Darwin Print, Hukum Acara Pidana dan Praktek, Jakarta, Djembatan, 1998

Hartono, Penyidikan dan Penegakan Hukum Pidana melalui Pendekatan Hukum Progresif, Jakarta, Sinar Grafika, 2010,

Heriyanto, otonomi daerah bidang Pertanahan. Karya tulis ilmiah. Yogyakarta, FH UII. 2010

http://pusda.situbondokab.go.id/cp-adm/progis/output/report.php?id=422

(kebenaran atas informasi ini dibenarkan oleh Ka.Sat.Pol.PP dalam konsultasi

Publik Raperda PPNS Kabupaten Situbondo, tanggal 22 April 2016)

I. Nyoman Sumaryadi, Efektifitas Implementasi Kebijakan Otonomi Daerah, Jakarta, Citra Utama, 2005

Ibad, S. Kewenangan Badan Perencanaan Pembangunan Kota (Bappeko) Malang Dalam Perencanaan, Kordinasi, Dan Pengendalian Tata Ruang Kota. DIALEKTIKA : Jurnal Ekonomi Dan Ilmu Sosial, 1(2), 23-48 2018. https://doi.org/10.36636/dialektika.v1i2.68

Jur Adi Hamzah, Hukum Acara Pidana Indonesia, Jakarta, Sinar Grafika, 2012

Lilik Mulyadi, Bunga Rampai Hukum Pidana: Perspektif, Teoretis dan Praktik, Bandung, Alumni,2008

M. Laica Marzuki dalam Berjalan-jalan di ranah hukum. Edisi revisi cetakan kedua. Sekretariat Jenderal dan kepaniteraan MK RI, Jakarta: 2006

M.Yahya Harahap, Pembahasan Permasalahan dan Penerapan KUHAP Penyidikan dan Penuntutan, Jakarta, Sinar Grafika, 2010

Ni`matul Huda, Hukum Pemerintahan Daerah, Bandung: Nusa Media 2009

Peter Mahmud Marzuki, Penelitian Hukum, Cetakan Pertama, Jakarta: Kencana Prenada Media, 2009

Romli Atmasasmita, , Sistem Pedadilan Pidana, prespektif Eksistensialisme dan Abilisionisme, Bandung : Bina Cipta, 1996

Ryaas Rasyid, Makna Pemerintahan : tinjauan dari segi etika dan kepemimpinan, Yarsif Watampone, Jakarta, 2000

S.H. Sarundajang, Arus Balik Kekuasaan Pusat ke Daerah, Jakarta,Pustaka Sinar Harapan, 2000

Sastra Djatmika dan Marsono, Hukum Kepegawaian Indonesia, Djambatan, Jakarta, 1995

Soerjono Soekanto dan Sri Mamudji, Penelitian Hukum Normatif: Suatu Tinjauan Singkat, Jakarta: RajaGrafindo Persada, 2007

Sulityowati Irianto dan Shidarta, Metode Penelitia Hukum: Konstelasi dan Refleksi, Jakarta: Yayasan Obor Indonesia, 2009

Teguh Prasetyo, Kriminalisasi Dalam Hukum Pidana, Bandung: Nusa Media, 2010 
W.J.S Poerwadarminta, Kamus Besar Bahasa Indonesia, Balai Pustaka, Jakarta, 1986

Zulkarenaen Koto, Terobosan Hukum Dalam Penyederhanaan Proses Peradilan Pidana, Jakarta : Jurnal Studi Kepolisian, STIKI, 2011

Undang-undang Dasar Tahun 1945 tentang Pemerintahan Daerah

Undang undang Nomor 8 TAHUN 1981 tentang Hukum Acara Pidana (KUHAP)

PP No. 58 Tahun 2010 Perubahan PP No. 27 Tahun 1983 Tentang Pelaksanaan Kitab Undangundang Hukum Acara Pidana

Undang undang Nomor 2 Tahun 2002 tentang Kepolisian Negara

Undang-Undang Nomor 9 Tahun 2015 tentang Perubahan Atas Undang-Undang Nomor 23 Tahun 2014 tentang Pemerintahan Daerah

Peraturan Pemerintah Republik Indonesia Nomor 79 Tahun 2005 tentang Pedoman Pembinaan dan Pengawasan Penyelenggaraan Pemeritahan Daerah

Peraturan Pemerintah Republik Indonesia Nomor 58 Tahun 2005 tentang pengelolaan keuangan daerah

Laporan berkala Sat. Pol. PP Kabupaten Situbondo, Triwulan I

hasil konsultasi Publik I Raperda PPNS, tanggal 22 April 2016

Hasil pengumpulan data empirik Raperda PPNS Kabupaten Situbondo

Hasil Validasai data data empirik Raperda PPNS Kabupaten Situbondo

Peraturan Pemerintah Republik Indonesia Nomor 24 Tahun 2016 Tentang Perubahan Atas

Peraturan Pemerintah Nomor 37 Tahun 1998 Tentang Peraturan Jabatan Pejabat Pembuat Akta Tanah. 